\title{
EPIPHORA DUE TO WEAK LID MUSCLES*
}

\author{
BY
}

\author{
H. BASIL JACOBS \\ London
}

IN a series of about 350 cases of epiphora referred to a special clinic for investigation, fourteen appeared to be associated with weakness of the orbicularis oculi, and were benefited by exercising the lid muscles.

\section{Physiology}

The concept that weak muscles may play a part in the causation of watering of the eye is based on the belief that the action of the orbicularis oculi plays a signal role in tear drainage. Since there is no wide agreement on this subject a review of the relevant theories is justifiable.

The tears are conducted from their main site of formation in the upper and outer part of the conjunctival sac to the inner canthus by capillary action. This is made plain by watching the spread of a drop of fluorescein instilled into the conjunctiva: it spreads immediately from one canthus to the other. It is not necessary to invoke the massaging action of the lids, but it is required that they should not be so slack that pooling can occur in the lower fornix, thus nullifying the capillary properties of the tears.

The mechanism of tear drainage from the puncta to the nose by way of the canaliculus, lacrimal sac, and naso-lacrimal duct has been the subject of much theorizing but little experiment. The results have been variable and contradictory, and often more significance has been read into them than was perhaps justifiable. The theories which have been put forward fall into two groups:

\section{(A) In which the action of the orbicularis oculi is NOT invoked}

(1) Siphonage - This was postulated by Petit (1734) as a possible mechanism for the flow of tears from the conjunctival sac to the nose, the siphon tube being the whole naso-lacrimal pathway. It is impossible to disprove this theory, but it seems unlikely that a continuous column of tear fluid exists in the entire tear-way. If siphonage does occur, it must be subsidiary to another mechanism.

(2) Capillarity.-This was thought to be important by Molinelli (1773), and possibly functions in conjunction with the action of the orbicularis muscle. However, at the lower end of the naso-lacrimal duct, capillarity would tend to prevent the tear flow of tears into the inferior meatus. 
(3) Gravity.-This is not essential to the flow of tears, as epiphora does not occur in subjects who are lying with their heads horizontal or even upside down. However, it has been shown that the flow of tears is faster when the head is vertical.

(4) Aspiration from the Nose.-This idea was suggested as a possible mechanism by Hunauld (1738), and many authors have favoured it. However, it has been shown that the necessary negative pressure to aspirate tears does not develop in the nose.

All the above theories seem to be made less cogent by the fact that epiphora occurs when the orbicularis oculi muscle is paralysed. The first three mechanisms described may play some part in tear drainage since they reflect the physical properties of a fluid in a tube system, but they are unlikely to be major factors. It is only exceptionally that tears will drain in the absence of lid action (Schirmer, 1903; Hoppe, 1909).

\section{(B) In which the action of the orbicularis oculi IS invoked}

(1) Lacrimal Sac Theories.-These have been put forward by many authors who demonstrated a rise in pressure in the lacrimal sac on blinking (Arlt, 1855; Weber, 1863; Rochat and Benjamins, 1915; Frieberg, 1917). It was postulated on anatomical grounds (Hyrtl, 1833; Schirmer, 1903) that tear flow was associated with a dilatation of the sac; an extension of this hypothesis was that the upper palpebral portion of the orbicularis was responsible for dilatation of the sac and Horner's muscle for its compression (Henke, 1858). There is no proof of this, however, and Rosengren (1928) maintained that the anatomy of the region was so complex that it might be interpreted as supporting any theory; any such anatomical evidence can give no support to the importance of the sac in tear conduction. Rosengren further stated that pressure changes in the sac were so small and variable as to be inconsiderable. In his own experiments, he explained the rise and fall of pressure in the sac on blinking as being secondary to a pumping action of the canaliculus and to a passive dilatation of the sac respectively. The persistence of the pressure rise in the sac was said to be due to a valve action at the entrance of the canaliculus, a fall in pressure occurring if this valve did not work. More recent research (Ploman, Engel, and Knutsson, 1928; Ploman, 1930) has shown by radiological volumetric experiments that there is a diminution in the volume of the sac on winking which becomes more marked on forcible contraction of the orbicularis. This was shown (radiologically) to occur in the lower part of the sac, there being an indefinite enlargement of the upper part. The changes were equivalent to a rise in the level of from 0.5 to less than $2 \mathrm{~mm}$. (average $1 \mathrm{~mm}$.) in an $0 \cdot 1-\mathrm{ml}$. capillary tube $225 \mathrm{~mm}$. high (i.e. the changes were small). The view that the dilatation and compression of the upper and lower parts of the sac in an alternating and reciprocal fashion is of much importance in tear conduction is also to be doubted on the ground that when the lower part of the sac is compressed there is no more reason for tears to go down (the upper part being dilated) than up. Gravity is unlikely to be important in so narrow a duct, as capillarity will tend to work against it. An additional reason for doubt is that drainage can occur when the action of the sac has been destroyed surgically. Although it is certain that these changes in volume do occur, it should be remembered that "the incidental 
effects of mechanical arrangements may be mistaken for functional necessities" (Proetz, 1953). Rosengren's careful experiments on pressure changes in the sac weigh heavily against the lacrimal sac theory.

(2) Canaliculus Theories.-These date from a suggestion of Richerand (1802). A peristaltic action (Béraud, 1856; Schirmer, 1903) and a compression during blinking (Foltz, 1860; Schirmer, 1903) were proposed as possible mechanisms. It was further suggested (Frieberg, 1917) that an increase in girth of that part of the orbicularis oculi which surrounds the canaliculus might press upon it and expel its fluid content into the conjunctival sac. Between blinks the canaliculus would dilate and suck tears in from the conjunctival sac. This author thought that there was a valve at the punctum to prevent regurgitation, but there is convincing evidence to the contrary (Ashikaga, 1922, Rosengren, 1928). Foltz (1860) thought that there were valves at the ampulla and at the entrance of the canaliculus into the sac, but there is no evidence in support of the presence of true valves. Rosengren performed experiments on animals (calf, pig, and sheep) in which he intubated the canaliculus and lacrimal sac, the latter in a backward direction from the nose, and recorded the pressure changes within both these organs. He concluded that tear drainage depended on the action of the orbicularis on the canaliculus, or on the canaliculus and the sac, and that gravity also played some part. In clinical experiments on man, using similar techniques, he made the following observations:

(a) variable changes in pressure occurred in the lacrimal sac on blinking; when the catheter was near the sinus of Maier rises in pressure were recorded;

(b) pressure increased in the canaliculus on blinking.

He concluded, therefore, that fluid was sucked into the canaliculus between blinks and expelled into the lacrimal sac during blinking. He did not consider gravity to be important in man because of the narrowness of the passages.

Experiences with dye tests indicate that when the orbicularis is forcibly contracted there may be some regurgitation into the conjunctival sac, and that there is no true valve mechanism at the punctum. Moreover, such a mechanism is not functionally necessary, for, even if some tear fluid regurgitated from the canaliculus into the conjunctival sac, drainage could still be adequate. Normally, little or no drainage of tears need occur, and even a somewhat inefficient valveless mechanism can suffice to conduct the normal tear secretion towards the nose. It is only when the tear secretion becomes excessive or the mechanism subnormally efficient that epiphora will occur.

Against the canaliculus theory is the fact that tears may continue to drain satisfactorily after the posterior wall of the canaliculus has been removed. In the absence of the posterior wall of the canaliculus, the underlying tissues act as a point d'appui for the contraction of the rest of the canaliculus (Frieberg, 1917), and the considerable pressure that can develop in the conjunctival sac on blinking may be communicated to the open canaliculus.

(3) Conjunctival Sac Theory.-This was first put forward by Petit (1734), who stated that a rise in pressure in the conjunctival sac on blinking was the propelling force in tear conduction. Rosengren (1928) confirmed the existence of this rise 
in pressure, which is quite considerable, but did not think it to be of great significance unless the canalicular function were grossly impaired by a large three-snip operation. Duke-Elder (1938) suggested that the conjunctival sac pressure had normally nothing to do with tear conduction.

In summation of the theories of tear conduction, it may be said that the weight of evidence, based chiefly on the work of Rosengren (1928) and of Rosengren and Kugelberg (1935), indicates that the mechanism is probably as follows:

The tears are secreted by the lacrimal gland in the upper and outer reaches of the conjunctival sac, and there is then a capillary spreading so that the tear film forms a thin layer over the rest of the conjunctiva and menisci at the lid borders. At the inner canthus, the canaliculus sucks in tears between blinks and expels them into the lacrimal sac on blinking. This causes a secondary fleeting rise in pressure in the sac so that drainage down the naso-lacrimal duct tends to occur.

\section{Clinical Review}

It is well known that epiphora can occur as an incidental feature in patients with Bell's palsy, even though the punctum may remain in the normal position. However, it is not so generally recognized that epiphora may be due to muscle weakness without obvious paresis. The clinical material on which this new concept is based is reviewed in detail below.

Frequently, the basis of the diagnosis has been the patient's failure to respond to accepted methods of treatment and the success achieved by therapy designed to improve the strength and tone of the orbicularis oculi. The patient is instructed to exercise the muscles by a slow sustained winking movement or a straining visual effort twenty times, three times daily. In some cases the treatment is continued for some months and, in one or two, it has been supplemented by faradism. It is important to avoid forcible lid closure, as the upper lid may catch behind the lower, everting the punctum.

Fourteen cases are summarized in the Table (overleaf), in which standard classifications of the position of the punctum and the strength of the orbicularis muscle are used as follows:

\section{Position of the Punctum}

I. Normal. The punctum cannot be seen, even on elevation of the gaze.

II. The punctum is visible but probably still able to effect the drainage of tears.

III. The punctum is more everted and is probably unable to effect drainage of the tears.

IV. The eversion is so marked that the punctum certainly cannot drain the tears efficiently.

Strength of the Orbicularis Oculi.-Dynamometric measurements of muscle strength in normal patients (Jacobs, 1954) gave average readings of 120$140 \mathrm{~mm}$. Hg. 
TABLE

HISTORY AND RESULTS

\begin{tabular}{|c|c|c|c|c|c|c|c|c|c|c|}
\hline \multirow{2}{*}{$\begin{array}{l}\text { Case } \\
\text { No. }\end{array}$} & \multirow[b]{2}{*}{ Sex } & \multirow{2}{*}{$\begin{array}{l}\text { Age } \\
\text { (yrs) }\end{array}$} & \multirow{2}{*}{$\begin{array}{l}\text { Occupa- } \\
\text { tion }\end{array}$} & \multicolumn{2}{|c|}{ Watering Eye } & \multirow{2}{*}{$\begin{array}{c}\text { Previous } \\
\text { Treatment } \\
\text { without } \\
\text { Benefit }\end{array}$} & \multirow{2}{*}{$\begin{array}{c}\text { Conjunc- } \\
\text { tiva }\end{array}$} & \multirow{2}{*}{$\begin{array}{l}\text { Position } \\
\text { of } \\
\text { Punctum } \\
\text { (see text) }\end{array}$} & \multicolumn{2}{|c|}{$\begin{array}{l}\text { Schirmer's } \\
\text { Test (mm.) }\end{array}$} \\
\hline & & & & Side & $\begin{array}{c}\text { Duration } \\
\text { (yrs) }\end{array}$ & & & & R. & L. \\
\hline 1 & $F$ & 42 & $\begin{array}{l}\text { Music } \\
\text { teacher }\end{array}$ & R. & 4 & $\begin{array}{l}\text { Probing and } \\
\text { syringing }\end{array}$ & White & R. II & Equal & \\
\hline 2 & $\mathbf{F}$ & 49 & Clerk & $\mathbf{R}$. & 1 & $\begin{array}{l}\text { Probing and } \\
\text { three syring- } \\
\text { gings }\end{array}$ & Pink & R. II & $\begin{array}{l}\text { Nearly } \\
\text { equal }\end{array}$ & \\
\hline 3 & $F$ & 40 & Clerk & L. & $10 / 12$ & $\begin{array}{l}\text { Syringing } \\
\text { (some bene- } \\
\text { fit) }\end{array}$ & $\begin{array}{c}\text { Slightly } \\
\text { pink }\end{array}$ & L. I & 25 & 5 \\
\hline 4 & $\mathbf{F}$ & 59 & $\begin{array}{c}\text { House- } \\
\text { wife }\end{array}$ & $\mathbf{R}$. & 12 & $\begin{array}{l}\text { Five probings, } \\
\text { many syring- } \\
\text { ings, and } 3- \\
\text { snip opera- } \\
\text { tion }\end{array}$ & White & R. I & $\begin{array}{r}\text { About } \\
\text { equal }\end{array}$ & \\
\hline 5 & F & 47 & Waitress & L. & 3 weeks & $\begin{array}{l}\text { Six pressure } \\
\text { syringings }\end{array}$ & White & L. II & Equal & \\
\hline 6 & $F$ & 47 & $\begin{array}{c}\text { House- } \\
\text { wife }\end{array}$ & $\mathbf{R}$. & $9 / 12$ & $\begin{array}{c}\text { Treatment at } \\
\text { eye hospital }\end{array}$ & White & R. II & Equal & \\
\hline 7 & $F$ & 64 & $\begin{array}{l}\text { House- } \\
\text { wife }\end{array}$ & $\begin{array}{l}\text { R. } \\
\text { L. }\end{array}$ & $1^{1 \frac{1}{2}}$ & $\begin{array}{c}\text { Four syring- } \\
\text { ings }\end{array}$ & White & $\begin{array}{l}\text { R. II } \\
\text { L. I }\end{array}$ & Equal & \\
\hline 8 & $\mathbf{M}$ & 47 & $\begin{array}{r}\text { Timber } \\
\text { porter }\end{array}$ & L. & 1 & Syringing & White & L.I & Equal & \\
\hline 9 & $\mathrm{~F}$ & 61 & $\begin{array}{r}\text { House- } \\
\text { wife }\end{array}$ & L. & $6-7$ & Syringing & Healthy & $\begin{array}{l}\text { R. II } \\
\text { L. IV }\end{array}$ & 16 & 31 \\
\hline 10 & $\mathbf{F}$ & 62 & $\begin{array}{c}\text { House- } \\
\text { wife }\end{array}$ & $\mathbf{R}$. & $3-4$ & $\begin{array}{l}\text { Syringing and } \\
\text { drops }\end{array}$ & White & $\begin{array}{l}\text { R. II } \\
\text { L. IV }\end{array}$ & Equal & \\
\hline 11 & $F$ & 62 & $\begin{array}{c}\text { House- } \\
\text { wife }\end{array}$ & $\mathbf{R}$. & $2-3 / 12$ & $\begin{array}{l}\text { Syringing and } \\
\text { drops }\end{array}$ & White & $\begin{array}{l}\text { R. I } \\
\text { Lid pitch- } \\
\text { ed low }\end{array}$ & 32 & 21 \\
\hline 12 & $\mathbf{M}$ & 58 & $\begin{array}{l}\text { Civil ser- } \\
\text { vant }\end{array}$ & $\mathbf{R}$. & $1 \frac{1}{2}$ & $\begin{array}{l}\text { Syringing and } \\
\text { drops (only } \\
\text { slight bene- } \\
\text { fit) }\end{array}$ & White & F. Fair & $\begin{array}{l}\text { About } \\
\text { equal }\end{array}$ & \\
\hline 13 & $\mathbf{F}$ & 55 & $\begin{array}{l}\text { House- } \\
\text { wife }\end{array}$ & $\begin{array}{l}\text { Both. Right } \\
\text { worse and } \\
\text { uncomfort- } \\
\text { able }\end{array}$ & $14 / 12$ & $\begin{array}{l}\text { Three syring- } \\
\text { ings and Pri- } \\
\text { vine drops }\end{array}$ & $\begin{array}{l}\text { Very } \\
\text { slightly } \\
\text { pink }\end{array}$ & $\begin{array}{l}\text { R. I } \\
\text { Lower lid } \\
\text { slack }\end{array}$ & Equal & \\
\hline 14 & $\mathbf{M}$ & 65 & Retired & L. & $4-5 / 12$ & Not noted & Healthy & $\begin{array}{l}\text { R. I } \\
\text { L. II }\end{array}$ & 4 & 4 \\
\hline
\end{tabular}

* No dye test performed 


\section{IN FOURTEEN CASES}

\begin{tabular}{|c|c|c|c|c|c|c|}
\hline \multirow{2}{*}{\multicolumn{2}{|c|}{$\begin{array}{l}\text { Strength of } \\
\text { Orbicularis Oculi } \\
\text { (mm. Hg) }\end{array}$}} & \multirow{3}{*}{$\begin{array}{l}\text { Initial } \\
\text { Dye Test }\end{array}$} & \multirow{3}{*}{ Syringing } & \multicolumn{2}{|r|}{ Exercises } & \multirow{3}{*}{ Remarks } \\
\hline & & & & \multirow{2}{*}{$\underset{(w k s)}{\text { Duration }}$} & \multirow{2}{*}{ Results } & \\
\hline $\mathbf{R}$. & L. & & & & & \\
\hline 120 & 112 & $*$ & Easy & 6 & Cụred & $\begin{array}{l}\text { Mother had had epi- } \\
\text { phora }\end{array}$ \\
\hline 78 & 84 & * & Easy & 6 & Almost normal & - \\
\hline \multicolumn{2}{|c|}{$\begin{array}{l}\text { Normal but digital } \\
\text { pressure gave sense } \\
\text { of weakness }\end{array}$} & $*$ & Easy & 8 & $\begin{array}{l}\text { Improved. Fluores- } \\
\text { cein drained norm- } \\
\text { ally }\end{array}$ & - \\
\hline 118 & 120 & * & Easy & 2 & Cured & $\begin{array}{l}\text { Mother had had epi- } \\
\text { phora }\end{array}$ \\
\hline 155 & 116 & $\begin{array}{l}\text { Poor drain- } \\
\text { age }\end{array}$ & Generally easy & $2-3$ & $\begin{array}{l}\text { No epiphora. Fluo- } \\
\text { rescein drained } \\
\text { well }\end{array}$ & $\begin{array}{l}\text { Watering of both eyes } \\
5 \text { years before had } \\
\text { settled spontaneously } \\
\text { after } 2 \text { years }\end{array}$ \\
\hline 120 & 118 & $*$ & Easy & 26 & Considerably better & $\begin{array}{c}\text { Onset followed head } \\
\text { cold }\end{array}$ \\
\hline 170 & 127 & Equivocal & Easy & $12-16$ & $\begin{array}{l}\text { R. Subjectively } \\
\text { cured but dye test } \\
\text { unchanged } \\
\text { L. Cured and dye } \\
\text { test normal }\end{array}$ & - \\
\hline 120 & 110 & * & Easy & 4 & Watering ceased & $\begin{array}{l}\text { Onset followed head } \\
\text { cold with discharge } \\
\text { from left eye }\end{array}$ \\
\hline- & - & * & Easy & 4 & Cured & Worse in last few weeks \\
\hline 115 & 105 & $*$ & Easy & $?$ & $\begin{array}{l}\text { R. Better } \\
\text { L. Cautery to im- } \\
\text { prove position of } \\
\text { punctum }\end{array}$ & $\begin{array}{l}\text { Complained of redness } \\
\text { and discomfort in right } \\
\text { eye }\end{array}$ \\
\hline 60 & 70 & $\begin{array}{l}\text { No drain- } \\
\text { age }\end{array}$ & Easy & $\begin{array}{l}\text { Failed to } \\
\text { attend } \\
\text { clinic }\end{array}$ & $\begin{array}{l}\text { Very little epiphora } \\
9 \text { mths later }\end{array}$ & $\begin{array}{l}\text { Father had had watery } \\
\text { eye }\end{array}$ \\
\hline 118 & 100 & $\begin{array}{l}\text { No drain- } \\
\text { age }\end{array}$ & Easy & 13 & $\begin{array}{l}\text { No improvement } \\
\text { (but see remarks) }\end{array}$ & $\begin{array}{l}\text { Father and two siblings } \\
\text { with epiphora. Fluor- } \\
\text { escein drained well } 6 \\
\text { weeks after faradism }\end{array}$ \\
\hline 163 & 115 & $\begin{array}{l}\text { R. } \text { No } \\
\text { drainage } \\
\text { L. } \quad \text { Free }\end{array}$ & $\begin{array}{l}\text { R. Patent } \\
\text { with pressure } \\
\text { L. Easy }\end{array}$ & 8 & $\begin{array}{l}\text { Much better } \\
\text { Normal drainage }\end{array}$ & $\begin{array}{l}\text { Aureomycin 4-hrly for } \\
2 \text { wks both eyes and } \\
\text { Privine 4-hrly to right } \\
\text { eye was followed by } \\
\text { cure to left. } 2 \text { syring- } \\
\text { ings gave no objective } \\
\text { improvement }\end{array}$ \\
\hline 80 & 92 & * & Easy & 13 & Almost cured & $\begin{array}{c}\text { One sister had watery } \\
\text { eye }\end{array}$ \\
\hline
\end{tabular}

before treatment was started. 


\section{DisCUSSION}

All the patients included in the Table were benefited by exercising the orbicularis oculi muscles. The facts concerning each case are indisputable, but the conclusion that the primary fault was a muscle weakness must be explored for fallacies.

The improvement that follows treatment for any condition may be due to the treatment and its designed effects, the treatment and its incidental effects, and/or a spontaneous incidental cure.

In these exercises for epiphora the designed effect is a strengthening and improvement in tone of the orbicularis oculi so that its pumping action in tear drainage may be restored to normal.

The incidental effects include the restoration of a mildly everted punctum and the resolution of vascular stasis and oedema of the walls of the canaliculus and sac by the increased muscle action. Muscular activity favours venous drainage in other parts of the body, and is likely to have a similar effect in the tissues of the eyelid.

The improvement may arise spontaneously, however, through the incidental cure of some unrecognized disorder; for example, a state of congestion and swelling hindering drainage at any point on the naso-lacrimal pathway. It is the writer's impression that the site of entrance of the canaliculus into the sac is one such point and that the consequent difficulty of passing a probe may lead to an unjustifiable diagnosis of stricture of the canaliculus. Such swelling is also important in the confined space occupied by the naso-lacrimal duct.

In the present series, Cases 1, 2, 5, 6, 7, 9, 10, and 14 all had a mild eversion of the punctum, but other patients are seen with an apparently equivalent condition who do not suffer from epiphora. This difference may be due to the failure or otherwise of the punctum in making contact with the tear film at some stage during the process of blinking. In these eight cases improvement followed the exercises, and it is legitimate to explain the improvement in terms of an improvement of muscle function.

Case 4 reacted so dramatically to treatment by exercise and had made so little response to other measures over a period of years that her cure must have been due to an improvement in the function of the orbicularis oculi.

Though it is possible that Cases 3, 8,11,12, and 13 improved because of some incidental effect or spontaneous development, the orbicularis exercises were followed by a satisfactory clinical response.

The diagnosis of weak muscles is difficult and rests on a favourable response to exercises and the failure of other accepted methods of treatment. It was found that dynamometer readings of the strength of the lid muscles were not always helpful, as average or even high measurements were sometimes obtained in patients in whom the muscle tone appeared to be deficient clinically. Lower lids that are pitched below the normal level or feel unduly 
slack in tone, and puncta out of position are useful but not wholly reliable clinical guides.

\section{SUMMARY}

A review of the theories of tear drainage is given. Fourteen cases of epiphora that were benefited by exercising the lid muscles are described and discussed.

Exercises were not found to benefit very elderly patients.

\section{REFERENCES}

ARLt, F. von (1855). v. Graefes Arch. Ophthal., 1, pt. 2, p. 135.

AshikaGA, . (1922). Klin. Mbl. Augenheilk., 68, 265 (Nippon Ganka Gakkai Zasshi, April, 1921). BÉrAUD, B. J. (1856). "Eléments de physiologie”, 2nd ed., vol. 1. Baillière, Paris.

DUKe-ElDER, S. (1938). "Text-book of Ophthalmology", vol. 1, p. 653. Kimpton, London.

Foltz (1860). Ann. Oculist. (Paris), 43, 227.

FrIEBERG, T. (1917). "Über die Mechanik de Tränenableitung". Inaug. Diss., Stockholm. $Z$. Augenheilk., 37, 42, 211, 324 (Cited by Rosengren, 1928).

Henke, W. (1858). v. Graefes Arch. Ophthal., 4, pt. 2, p. 70.

HopPe, J. (1909). Klin. Mbl. Augenheilk., 47, Suppl., p. 66.

Hunauld, F. J. (1738). Phil. Trans. (for 1735-36), 39, 54.

HYRTL, J. (1853). "Handbuch der topographischen Anatomie", 2nd ed., vol. 1, p. 154. Braumüller, Vienna.

JACOBS, H. B. (1954). Brit. J. Ophthal., 38, 560.

Molinell, (1773). "Mémoires de l'académie de sciences de l'institut de Bologne", p. 17.

PETIT, J. L. (1734). " "Sur le fistule lacrymale”. Mémoires de l'academie de sciences de Paris, p. 135. Ploman, K. G. (1930). Acta ophthal. (Kbh.)., 8, 155.

- ENGEL, A., and KNUTSSON, F. (1928). Ibid., 6, 55

Proetz, A. W. (1953). "Essays on the Applied Physiology of the Nose", 2nd. ed. Annals Publishing Co., St. Louis, U.S.A.

Richerand, B. A. (1802). "Nouveaux éléments de physiologie", 2nd. ed. Crapart, Caille, and Ravier, Paris.

Rochat, G. F., and Benjamins, C. E. (1915). v. Graefes Arch. Ophthal., 91, 92.

RoSENGREN, B. (1928). Svenska Läk.-Sällsk. Handl., 54, 41.

and Kugelberg, I. (1935). Klin. Mbl. Augenheilk., 95, 764.

SCHIRMER, O. (1903). v. Graefes Arch. Ophthal., 65, 197.

Weber, A. (1863). Klin. Mbl. Augenheilk., 1, 63. 